\title{
ENDOSCOPIC MANAGEMENT OF BILIARY COMPLICATIONS AFTER LIVER TRANSPLANTATION
}

\author{
A terapêutica endoscópica nas complicações biliares pós-transplante hepático \\ Jeany Borges e Silva RIBEIRO ${ }^{1}$, Fabrício de Sousa MARTINS ${ }^{1}$, José Huygens Parente GARCIA ${ }^{2}$, \\ Adriano César Costa CUNHA ${ }^{1}$, Ricardo Augusto Rocha PINTO ${ }^{1}$, Marcus Vallerius SATACASO ${ }^{1}$, \\ Francisco Paulo Ponte PRADO-JÚNIOR ${ }^{1}$, Ricardo Rangel de Paula PESSOA ${ }^{4}$
}

From 1Cesar Calls General Hospital, Fortaleza, CE and 2Walter Cantídio University Hospital, Federal University of Ceará, Fortaleza, Ce, Brazil

HEADINGS - Liver transplantation. Biliary fistula. Cholangiopancreatography, endoscopic retrograde.
ABSTRACT - Background - Liver transplantation is the only effective treatment for chronic liver diseases and terminal survival rate has increased in recent decades. However, biliary complications have high incidence and remain as the "Achilles heel" for liver transplantation. Aim - To evaluate retrospectively endoscopic treatment outcomes of biliary complications in post-liver transplantations. Methods - The sample consisted of post-liver transplantation patients for endoscopic retrograde cholangiopancreatography due to suspected biliary complications. Results - Fifteen patients were included (10 male, mean age of 49.57 years) and 36 endoscopic retrograde cholangiopancreatographies were undertaken (2.4/patient). Biliary stricture was diagnosed in 13 patients and endoscopic treatment was successful in $56 \%$ (38,46\% still in treatment). Biliary leaks were found in one patient and dysfunction of the hepatobilliary ampulla with choledocholithiasis was diagnosed in one patient, both cured by endoscopic treatment. Conclusions - Post-liver transplantation biliary complications are relatively common and endoscopic treatment may result in satisfactory outcome. Stenosis was the more frequent complication in this series.

\section{Correspondence:}

Jeany Borges e Silva Ribeiro

Capitão Francisco Pedro Street, n. 1016/105,

Fortaleza, CE, Brazil. ZIP code: 60430372.

Financial source: none

Conflicts of interest: none

Received for publication: 04/06/2012 Accepted for publication: 22/08/2012

DESCRITORES - Transplante hepático. Fístula biliar. Pancreatocolangiografia retrógrada endoscópica.
RESUMO - Racional - O transplante hepático é o único tratamento efetivo para as hepatopatias crônicas terminais e a taxa de sobrevida tem aumentado nas últimas décadas. No entanto, as complicações biliares têm alta incidência e permanecem como o "calcanhar de Aquiles" do transplante de fígado. Objetivo - Avaliar retrospectivamente os resultados do tratamento endoscópico das complicações biliares em pacientes submetidos à transplante hepático. Métodos - Foram avaliados pacientes transplantados hepáticos para realização de colangiopancreatografia retrógrada endoscópica por suspeita de complicação biliar. Resultados - Quinze pacientes (11 homens, média de idade de 49,57 anos) foram estudados. Nesse período foram realizadas 36 colangiopancreatografias retrógradas endoscópicas (2,4/paciente). Neste grupo, 100\% receberam órgão de doador falecido. Estenose da anastomose coledococoledocociana foi diagnosticada em 13 pacientes e o sucesso da terapêutica endoscópica foi de 53,84\% (38,46\% ainda em tratamento). Fístula biliar foi diagnosticada em um paciente, sendo resolvida pelo tratamento endoscópico. Disfunção da âmpola hepatopancreaticobiliar com coledocolitíase foi diagnosticada em um paciente, também resolvida pela terapêutica endoscópica. Conclusões - As complicações biliares pós-transplante hepático são relativamente comuns, com predominância de estenoses. O tratamento endoscópico foi eficaz na maioria dos pacientes desta série.

\section{INTRODUCTION}

$\mathrm{T}$ he liver transplantation is a procedure that saves the lives of patients with end stage chronic liver disease or acute liver failure when no other clinical and surgical treatments are available. Since the first liver transplantation was carried out by Thomas Starzl in 1963, significant advances have occurred in all aspects of the selection, preservation, recovery and organ implantation techniques. The survival rate at one year for adults and children transplanted from cadaver donor is greater than $85 \%$, and it keeps over $70 \%$ and 
$60 \%$, respectively, at fifth and tenth years after implantation. However, the complications of biliary tract continue to be common source of morbidity and mortality. Some authors call them the "Achilles' heel" of liver transplantation².

Researches about long-term outcomes after liver transplantation indicate that $5 \%$ to $30 \%$ of recipients develop biliary complications after that procedure. Biliary stricture and fistula are the most common complications of bile ducts, but dysfunction of the sphincter of Oddi, hemobilia and biliary obstruction of the cystic duct for mucocele or calculations have been observed, too. The rate of biliary fistula or anastomotic site strictures are reported in $15 \%$ to $60 \%$ of recipients. These high rates of post-transplantation complications may mean the inherently sensitive nature of biliary epithelium to ischemic damage compared to hepatocytes and vascular endothelium ${ }^{2}$.

The surgical treatment is the traditional approach for biliary tract complications of liver transplantation. After advances in therapeutic and diagnostic endoscopy, the conservative treatment of biliary complications has become one of the most used methods².

The aim of this study is to evaluate retrospectively the results of endoscopic treatment of biliary complications in patients undergone to liver transplantation.

\section{METHODS}

Were evaluated 15 patients that undergone to liver transplantation (donor cadaver) forwarded to Cesar Calls General Hospital and to a private office for endoscopy in Fortaleza, Brazil, from December 2004 through July 2011, for performing Endoscopic Retrograde Cholangiopancreatography (ERCP) for suspected biliary post-transplantation complication. It was based on the elevation of liver enzymes or cholestatic liver disease, presence of fever, jaundice, pruritus, pain or choleperitonium after withdrawal of the biliary drainage system.

The ERCP and the appropriate therapy were performed individually, as the physician's indication at the time of the examination. The complications observed retrospectively after examination were classified in light (bacteremia, occlusion or migration of the prosthesis) and severe (acute pancreatitis, bleeding, perforation). The outcome of endoscopic treatment was deemed successful when clinical, laboratory or endoscopic appearance improvement happened. Treatment failure was defined as the lack of improvement of those parameters or the need of another therapeutic modality (surgical or percutaneous drainage).
RESULTS

Fifteen liver-transplanted patients were selected. Ten men and five women. Their mean age was 49.5 [2767] years.

The hepatitis C (5/33.3\%), the hepatitis $C$ and hepatocellular carcinoma association $(4 / 26.7 \%)$, the hepatitis B $(2 / 13,33 \%)$, the hepatites $B$ and Delta association $(2 / 13,33 \%)$, the hepatitis $B$ and alcoholic cirrhosis association (1/6,7\%) and alcoholic cirrhosis $(1 / 6,7 \%)$ were the causes of liver transplantation. Most recipients had advanced disease, and were classified as Child B and all received organ donor cadavers. The graft cold ischemia mean time was 5.7 hours and the graft warm ischemia mean time was $41.2 \mathrm{~min}$ (Table 1).

TABLE 1 - Demographic data, cirrhosis cause and ChildTurcotte-Pugh classification of patients undergone to ERCP after liver transplantation due to suspicion of biliary tract complication

\begin{tabular}{|c|c|}
\hline Parameters & Number (\%) \\
\hline \multicolumn{2}{|l|}{ Gender } \\
\hline Male & $10(66,67 \%)$ \\
\hline Female & $5(33,33 \%)$ \\
\hline Age (years) & $49,5$ (27 a 67$)$ \\
\hline \multicolumn{2}{|l|}{ Cause } \\
\hline $\mathrm{HCV}$ & $5(33,3 \%)$ \\
\hline $\mathrm{HCV}+\mathrm{HCC}$ & $4(26,7 \%)$ \\
\hline HBV & $2(13,33 \%)$ \\
\hline HBV+Delta & $2(13,33 \%)$ \\
\hline $\mathrm{HBV}+$ alcohol & $1(6,7 \%)$ \\
\hline Alcohol & $1(6,7 \%)$ \\
\hline \multicolumn{2}{|c|}{ Child-Turcotte-Pugh classification } \\
\hline A & 0 \\
\hline B & $7(58,33 \%)$ \\
\hline C & $5(41,67 \%)$ \\
\hline \multicolumn{2}{|l|}{ Graft ischemia time } \\
\hline Cold (hours) & $5,71 \mathrm{~h}$ \\
\hline Warm (minutes) & $41,27 \mathrm{~min}$ \\
\hline
\end{tabular}

ERCP = endoscopic retrograde cholangiopacreatography; $\mathrm{HCV}=$ hepatites $\mathrm{C}$ virus; $\mathrm{HCC}=$ hepatocellular carcinoma; $\mathrm{HBV}=$ hepatitis $B$ virus.

Biliary stenosis was diagnosed for 13 (86.7\%) patients, major papilla dysfunction associated with choledocholithiasis in one patient (6.67\%) and biliary fistula in one patient (6.67\%) (Table 2). The strictures were dilated with catheter or hydrostatic balloon, followed by prostheses placement as indicated by the endoscopist at the time of the examination. The mean time between the transplantation and the first ERCP was 12.6 months [1-69] in patients with stenosis. Two patients underwent ERCP belatedly, one of them after five years of transplant and another with more than two TABLE 2 - Cholangiographic findings in liver transplanted patients undergone to ERPC due to suspicion of biliary tract complication

\begin{tabular}{lc|}
\hline ERPC finding & Number (\%) \\
\hline Anastomotic stricture & $13(86,7 \%)$ \\
\hline Biliary fistula & $1(6,67 \%)$ \\
\hline Oddi's sphincter dysfunction + calculi & $1(6,67 \%)$ \\
\hline
\end{tabular}

$E R C P=$ endoscopic retrograde cholangiopancreatography 
TABLE 3 - Therapeutic endoscopy results for biliary tract stenosis of cadaver donor liver transplantation and comparison to literature

\begin{tabular}{|c|c|c|c|c|c|c|c|c|c|}
\hline Author & $\mathrm{n}$ & $\begin{array}{l}\text { Interval } \\
\text { LTx-1 } \\
\text { ERPC } \\
\text { (months) }\end{array}$ & $N^{\circ}$ ERPC & $\begin{array}{c}\text { Endoscopic } \\
\text { approach } \\
\text { success rate \% }\end{array}$ & $\begin{array}{l}\text { Treatment } \\
\text { modality }\end{array}$ & $\begin{array}{l}\text { Treatment } \\
\text { duration } \\
\text { (months) }\end{array}$ & $\begin{array}{l}\text { Follow-up time } \\
\text { without prosthesis } \\
\text { (months) }\end{array}$ & $\begin{array}{l}\text { Biliary anastomosis } \\
\text { stricture relapse \% }\end{array}$ & Complications \\
\hline Ribeiro,JBS et al & 13 & $12,69(1-69)$ & $2,53(1-5)$ & 53,84 & $\mathrm{BD} \pm$ prosthesis & $11,14(10-16)$ & 28(median) & 7,69 & - \\
\hline Rerknimitr et al. (2002) ${ }^{4}$ & 43 & $8.3(0.5-60)$ & $3.8(1-8)$ & 100 & $\mathrm{BD} \pm$ prosthesis & $15.8(1.5-40)$ & 39 (median) & 0 & 6.6 \\
\hline Thuluvath et al. $(2003)^{6}$ & 19 & - & $3.5(1-16)$ & 74 & $\mathrm{BD} \pm$ prosthesis & $3-6$ & 34(mean) & - & 12 \\
\hline Zoepf et al. (2006) ${ }^{7}$ & 25 & $5(1-33)$ & $4(1-11)$ & 88 & $\mathrm{BD} \pm$ prosthesis & $3.5(1-24)$ & 4(median) & 31 & 24 \\
\hline Holt et al. $(2007)^{1}$ & 53 & - & $3(2-4)$ & 69 & $\mathrm{BD} \pm$ prosthesis & $11.3(7-14)$ & 18 (median) & 3 & 20.7 \\
\hline Pasha et al. $(2007)^{3}$ & 25 & $2(0.2-24)$ & $3.5(1-9)$ & 88 & $\mathrm{BD} \pm$ prosthesis & $4.6(1.1-11.9)$ & 21.5 (median) & 18 & 5 \\
\hline
\end{tabular}

$\mathrm{LTx}=$ liver transplantation; $\mathrm{ERCP}=$ endoscopic retrograde cholangiopancreatography; $\mathrm{BD}=$ balloon dilator

years. During this study, 33 ERCP in 13 patients with stenosis were performed. The mean number of ERCP for each patient was 2.53 (1-5) (Table 3).

The success rate of endoscopic therapy in these cases was $53.84(7 / 13)$, and $38.46 \%(5 / 13)$ are still in treatment. One patient died during treatment due to hepatocellular carcinoma relapse. The patient with biliary fistula was successfully treated with plastic prosthesis through endoscopy. The patient with choledocholithiasis and hepatopancreaticoduodenal ampulla dysfunction was managed through papillotomy and withdrawal of calculi. The biliary prosthesis remaining mean time was 8.73 months $(0-16)$.

Amongst the 13 patients with anastomosis stricture, one of them had relapse of the stricture and he was treated endoscopically through balloon dilator, without prosthesis drawing. The follow-up median time after stricture correction was 28 months. (Table 3).

The post-transplantation follow-up median time was 27 months and varied from four to 86 months.

Amongst the patients with biliary stent prolonged permanence, bacteremia after ERCP and prosthesis obstruction occurred.

\section{DISCUSSION}

The scenario of the biliary complications after liver transplantation has changed rapidly in the last two decades. Conventional treatment of these conditions in the past was exclusively surgical. Therapeutic endoscopy, however, plays important role in the treatment of anastomotic stenosis. Currently, the preferred endoscopic approach is aggressive dilation of the stricture and insertion of multiple plastic stents. Percutaneous and surgical procedures are now reserved for patients with failure of endoscopic treatment and for those with multiple intrahepatic strictures or with inaccessibility due to Roux-en-Y anastomosis. Absorbable or recovered metal prostheses can provide superior results and deserve further investigation. The area of endoscopic therapy will continue to evolve and to offer opportunities to new innovative techniques of liver transplantation that develop biliary tract stenosis5.

Currently, ERCP is indicated for definition and treatment of biliary tract complications after liver transplantation, with satisfactory success rates because it avoids huge amounts of reoperations. Biliary tract complications can occur in $6 \%$ to $39.5 \%$ of patients undergone to liver transplantation, being more frequent after liver "inter vivos" transplantation. The development of complications can be determined by a number of factors, such as: disease, biliary operation, type of anastomosis, disproportion between the size of the donor and receiver biliary tracts, inadequate biliary tract extension of the graft and anatomical complexity of the right biliary tract, which can result in more than one branch anastomosis. Other important factors that can contribute to the development of biliary tract complication are: use of bile drains, infection (Cytomegalovirus, CMV) and ischemia ${ }^{5}$.

In this research, occurred a predominance of males and the mean age was 49.4 years, similar to that found in the literature consulted. The most frequent cause of liver transplantation was hepatitis $C$, also according to the literature. The most frequent diagnosis found was biliary tract stenosis, with a rate higher than found in the literature.

According to Rerknimitr et al. ${ }^{4}$, after analyzing the outcome of endoscopic therapy of 43 patients undergone to cadaver donor hepatic transplantation complicating with biliary anastomosis strictures, they observed a mean interval of 8.3 months $(0.5-60)$ between the transplantation and the ERCP, which is less than the value found in this series. In a similar series of 25 patients, Zoepf et al. ${ }^{7}$ found a mean interval of five months (1-33) and Pasha et al. ${ }^{3}$, in similar cases of 25 patients, found a mean interval of two months (0.2 $-24)^{2}$.

The mean amount ERCP per patient was 3.8 (1-8) in the Rerknimitr research ${ }^{4}$. Holt et al ${ }^{1}$ found endoscopic therapy success rate of $69 \%$, slightly higher than that found in this present study, using as a therapeutic modality the balloon dilator associated with the endoprosthesis, with a mean duration of endoscopic therapy of 11.3 months (7-14), also higher than found in this study. For Pasha7 et al, the median follow-up time without the prosthesis was 15 months, slightly higher than that of this research. About the anastomosis stricture relapse, Zoepf et al. ${ }^{7}$ reported a rate of $31 \%$, higher than this series rate. The rate of complications in a recent review published in the literature ranged from $5 \%$ to $24 \%^{2}$. 
Post-transplantation hepatic biliary complications are relatively common and the strictures are the most frequent one. The endoscopic treatment was effective in most patients in this series.

\section{REFERÊNCIAS}

1. Holt AP, Thorburn D, Mirza D, Gunson B, Wong T, Haydon G. A prospective study of standardized nonsurgical therapy in the management of biliary anastomotic strictures complicating liver transplantation. Transplantation 2007;84:857-863.

2. Martins FP, Tafarel JR, Ferrari AP. Terapêutica endoscópica nas complicações biliares pós-transplantes hepáticos. Einstein. 2008; 6(4):422-7

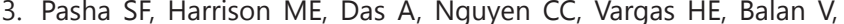
Byrne TJ, Douglas DD, Mulligan DC.. Endoscopic treatment of anastomotic biliary strictures after deceased donor liver transplantation: outcomes after maximal stent therapy. Gastrointest Endosc 2007;66:44-51.

4. Rerknimitr R, Sherman S, Fogel EL, Kalayci C, Lumeng L, Chalasani $\mathrm{N}$, Kwo P, Lehman GA.. Biliary tract complications after orthotopic liver transplantation with choledochocholedochostomy with whole-liver transplants. Transplant Proc 2005;37:1164-1166

5. Ryu CH, Lee SK. Biliary Strictures after Liver Transplantation. Gut and Liver. 2011; 5( 2):133-142.

6. Thuluvath PJ, Atassi T, Lee J. An endoscopic approach to biliary complications following orthotopic liver transplantation. Liver Int 2003;23:156-162.

7. Zoepf T, Maldonado-Lopez EJ, Hilgard P, Malago M, Broelsch CE, Treichel U, Gerken G.. Balloon dilatation vs. balloon dilatation plus bile duct endoprostheses for treatment of anastomotic biliary strictures after liver transplantation. Liver Transpl 2006;12:88-94. 